Original paper UDC 17:796(045)

1 Simon, Robert

doi: $10.21464 / \mathrm{sp} 34208$

Received: 4 December 2018

\author{
Miroslav Imbrišević \\ University of London, Heythrop College, 23 Kensington Square, Kensington, London W8 5HN, UK \\ miroslav.imbrisevic@heythropcollege.ac.uk
}

\title{
Robert Simon and the Morality of Strategic Fouling
}

\begin{abstract}
As sports have become more professional, winning has become more important. This emphasis on results, rather than sporting virtue and winning in style, probably explains the rising incidence of the Strategic Foul. Surprisingly, it has found some apologists among the philosophers of sport. The discussion of the Strategic Foul in the literature has produced subtle distinctions (e.g. Cesar Torres: constitutive skills versus restorative skills) as well as implausible distinctions (e.g. D'Agostino: 'impermissible' but 'acceptable' behaviour). In this paper I will review Robert Simon's defence of strategic fouling and conclude that his justification is not convincing.
\end{abstract}

Keywords

Robert Simon, strategic foul, professional sport, sporting virtue

\section{Introduction ${ }^{1}$}

Some sports are games, other sports are not. The verb 'play' helps us to identify them: we play cricket, football and basketball. However, we do not 'play' boxing. Boxing, like many martial endeavours (Tae-Kwon-Do or Karate), is more aptly described as an art. Similarly, we do not 'play' sprinting or highjump, presumably because there is not much room for playfulness in these sports. ${ }^{2}$ In this essay I will focus on sports such as football, basketball and hockey - not on card games, board games, video games and similar.

Although the rules of games proscribe fouls, they do occur in games. However, they are normally the result of accident rather than being deliberate; or if they are deliberate, the aim is not to gain an advantage (e.g. revenge for a previous tackle or asserting yourself after having been roughed up by the opposition). In football, for example, tackles which result in injuries are usually

1

I presented elements of this paper in Brno, Czech Republic (2017), in Zagreb \& Varaždin, Croatia (2018) and London, United Kingdom (2018), and I am grateful to the participants for their input. For detailed comments I wish to thank: Patrick Riordan, Gustavo Beade, Tobias Schaffner, Stephen McLeod, Sarah Pawlett Jackson, Peter Czerne, Alfred Archer, Jussi Saarinen and Mihail Evans.

\section{2}

But note that some sports commentators during the 2016 Summer Olympics in Rio de Janeiro (Brazil) referred to the Tae-Kwon-Do competitors as 'players' - this struck me as odd. And note that Bernard Suits thinks that sprinting and high-jump are games. 
not intended. ${ }^{3}$ They are due to bad judgement, clumsiness, a wet pitch, loss of self-control/affect (the Suarez biting incident), ${ }^{4}$ fatigue, etc. ${ }^{5}$ The same goes for many instances of hand-ball. ${ }^{6}$

In contrast, the purpose of a Strategic Foul (SF from hereon) is to retain an advantage even after the imposition of a penalty. Here the rule of a game is broken openly and deliberately, and the punishment is accepted willingly. ${ }^{7}$ Such a foul is also known as a 'tactical' or a 'professional' foul. After the imposition of the penalty, there remains an unearned advantage for the rulebreaker - unearned because it was gained through a foul, rather than through out-playing the opposition. ${ }^{8}$ Thus, the strategic fouler profits from wrong-doing. There is wide agreement that one should not profit from wrong-doing, not just in sport. ${ }^{9}$

The penalty for fouls is designed to restore the status quo ante, to take away any advantage which might have resulted from the foul. Patrick Riordan writes:

"This form of punishment is essentially restorative. It restores a pre-existing balance of fairness between the two teams." (Riordan 1996: 17)

The SF undermines the restorative function. The notion that the penalty compensates (Simon 2005; Simon et al. 2015; Flynn 2017) the victim for the wrong they have suffered, making the victim whole again, might have some plausibility when applied to non-SFs. However, in a SF the offending side is often better off after 'compensating' their victim. Here, the idea of adequate compensation for rule-breaking is misplaced - because the sanction does not fully restore the victim. In a non-SF compensation (i.e. the penalty) normally equals restoration; in a SF compensation and restoration are not aligned. Fairness requires that we take away from the wrong-doer those residual advantages which result from rule-breaking, even after the imposition of a penalty. In this way, we could restore the victim to the status quo ante. The rule-changes with regard to stopping-the-clock in the NBA from 2016 nicely illustrate that this is possible: the victim side now retains possession of the ball. ${ }^{10}$

When football was the preserve of gentlemen, committing a deliberate foul was bad form. Here is a voice from 1891, discussing the novel idea of the penalty kick in football:

"It is a standing insult to sportsmen to have to play under a rule which assumes that players intend to trip, hack, and push their opponents and to behave like cads of the most unscrupulous kind. I say that the lines marking the penalty area are a disgrace to the playing field of a public school." (McIntosh 1979: 80)

However, times have changed; the SF now frequently occurs in professional leagues.

Some philosophers of sport feel the need to vindicate certain instances of the $\mathrm{SF}$ and to incorporate the SF into their frameworks - probably because it has become a common occurrence. A frequently discussed example is the practice of stopping-the-clock at the end of a basketball game. ${ }^{11}$ But this accommodation of the SF requires, apparently, that they introduce implausible distinctions: the SF is 'impermissible' but 'acceptable' behaviour (D'Agostino 1981); the constitutive rules make room for the SF (Suits 2005); the 'true' foul versus the 'pseudo-foul' (Vossen 2014); "strategic fouling can be morally problematic and still be part of the game" (Russell 2017: 2), and lastly, there are two types of sanction for rule-breaking: compensation or punishment (Simon 2005). Due to limitations of space, the focus of this paper will 
be on Simon's account of strategic fouling, because Simon provides the most worked out defence of the practice.

Although the philosophical supporters of strategic fouling will only permit it in certain contexts, coaches and players are not so discriminating. Russell writes:

“... let's face it, strategic fouling is embraced in a wide range of circumstances beyond what Simon et al. contemplate, including when it is unclear or even unlikely that there is no other strategy that would give a contestant a reasonable opportunity to use their constitutive skills to win." (Russell 2017: 10)

My deliberations will address all instances of strategic fouling, rather than just those which find favour with philosophers of sport.

\section{Penalties as a Redistribution of Advantages}

Patrick Riordan states that sport assesses the skills of actors when measured by the same standards. Using strategic fouling would upset the scales (because one side would retain an unearned advantage) and make the act of fair measuring difficult or impossible. One of the most important aspects of fairness in games is that the actors compete against each other on equal terms. Riordan explains:

"The balance of fairness constitutes equality in one very fundamental sense: the teams can be very unequal in terms of skill, experience, reputation, height and strength, but they are equal in relation to the rules and conditions which apply to their contest. That equality was undermined by the offender's attempt to gain an advantage for his team in a forbidden action. The punishment attempts a redistribution of advantages with a view to restoring the balance of fairness." (Riordan 1996: 17)

This is merely my impression and I have no empirical data to back up my view. Of course if a player is going in 'hard', she may act negligently or may simply accept injury as an unintended by-product of her tackle.

"Luis Suarez bite: Uruguay striker banned for four months", BBC Sport (1 July 2014). Available at: https://www.bbc.co.uk/sport/football /28023882 (accessed on 4 December 2018).

See Kosiewicz (2011: 36) for a wider list of reasons for accidental fouls.

But see Maradona's 'Hand of God' goal at the 1986 World Cup (https://www.youtube.com/ watch? $\mathrm{v}=-\mathrm{ccNkksrfls)}$. This particular phrase suggests that Maradona did not deliberately use his hand, but that his hand was guided by God. Maradona plays on some ambiguity here because he was known as 'god' in Argentina. Note that recently IFAB changed the hand-ball rules (Couse, 2019).

This needs to be distinguished from the deceptive foul (e.g. diving in football or a handball out of view of the referee), which is a form of cheating. But this is clearly wrong and there is no controversy about this. The aim is to gain an advantage through fouling, but without being detected and thus without incurring a penalty. Some theorists would class the SF as a form of cheating; for a discussion see Russell (2014).

8

Unless you consider (some) rule-breaking to be a form of out-playing the opposition.

This is also reflected in the legal realm, particularly in the law of restitution; see Virgo (2015), Imbrišević (2020, forthcoming).

10

"NBA Board of Governors approves new rules regarding deliberate away-from-theplay fouls for 2016-17 season", NBA Communications (12 July 2016). Available at: https://pr.nba.com/nba-board-governors-newrules-away-from-the-play-fouls/ (accessed on 4 December 2018).

11

It is likely that the SF has been around for quite a while, especially if the stakes were high. Vamplew writes that the introduction of the penalty kick in football in 1891 "was designed to counteract the professional foul" (Vamplew 2007: 858). 
We need to remind ourselves that the SF is often employed in situations when the opposition has outplayed a team; this is usually the losing side or the side in a worse position. The only means left to alter the situation is to commit a foul - at least this is how it might appear to the losing side. Committing a foul has two effects: Firstly, it changes the 'natural' course of events, i.e. the flow of play is being interrupted by a SF, which might otherwise lead to a win for the side which is ahead in the score or in a better position to score. The second, related, effect is that because the penalties for SFs often do not restore the victim side to the status quo ante, but leave it with a disadvantage, the balance of fairness between competitors is undermined. It means that the result of the game does not represent a fair measure of the skills and performance of the competing teams any more (cf. Dixon 1999: 15).

One might ask: why don't the penalties have enough bite to deal with the SF? I answer: the rules of most popular games were not designed to deal with SFs - despite Suits' claim that they flow from the constitutive rules. ${ }^{12}$ It was just not like that, and the gamewrights did not envisage that players would foul openly and deliberately to gain an advantage.

Morgan (2012: 82f.) highlights the paradigm shift from the 19th-century amateur-gentleman, who learned how to play on the playing fields of Eton, to the turn-of-the-century American pragmatists, who learned how to win by applying strategic thinking. This clash of paradigms is illustrated nicely in the movie Chariots of Fire, where using a coach is considered bad form. Morgan argues that neither paradigm can claim normative preponderance. I want to add a third paradigm - it is the way we learn to play games as children. We are inculcated with the rules of a game, but we are normally not taught to use SFs. I would contend that these early experiences shape how we think (and feel) about rules and fouls. However, the professional athlete quickly learns to discard what they were taught in childhood. ${ }^{13}$

Although SFs most likely happened in ancient Greece and perhaps in times earlier, in the recent past ${ }^{14}$ winning was not the supreme value. Instead, it was playing the game as a fair measure of the standards required by the rules. Characterising the situation of today, we could say that a 'wily coach' ${ }^{15}$ has found more efficient means (i.e. the SF) to engineer victory, means which were not envisioned by the gamewright. Game rules are usually not self-reflective, i.e. there is no explicit rule which states that using a rule (which deals with penalties) to find a more efficient way to achieve the pre-lusory goal of the game subverts the overall purpose of the rules and spoils the game - and therefore this kind of use of rules is prohibited. Why are rules not self-reflective? The gamewright does not expect players to subvert the purpose of the rules (and of the game). ${ }^{16}$

For players the purpose of a match may vary: to score more goals than the opposition and thus to win the game; to aim for a draw or a win; to deliver a credible performance despite facing a superior opponent, etc. In contrast, the purpose of the game (as envisioned by the gamewright) is to provide a fair measure of skill and performance. The strategic fouler pursues a purpose which clashes with the purpose of the game.

\section{Robert Simon}

Simon's favourite example is stopping-the-clock in basketball. This SF leaves the fouling team with an advantage after the imposition of the penalties: possession of the ball (but note the NBA rule changes from 2016). 
According to Simon, sometimes the SF can be morally appropriate:

“... in specific contexts, particularly close games in basketball, the judicious use of preventive strategic fouls can be morally appropriate. For one thing, when the teams are evenly matched in constitutive skills, differences in restorative skills become relevant to determining which team has best met the test of the contest. Second, judicious strategic fouling in close basketball games raises the competitive intensity of the game and creates more of a test for the players than simply letting the leading team run out the clock. Third, some features of the rules create an incentive for teams to strategically foul at the end of close games in order to trade 2 points for a chance of making 3 , thereby calling into question whether in such contexts foul shots really are intended to be punishments for forbidden behavior or the price of strategic choices." (Simon 2005: 94f.)

Let us evaluate Simon's claims. What about close games where teams are evenly matched in constitutive skills? Warren Fraleigh (2003) argues that the sports contest should be measured through the display of constitutive skills rather than restorative skills (e.g. free-throws in basketball). Simon responds:

“... sometimes a sports contest in which restorative skills are employed can be a better test of more varied abilities than one in which only constitutive skills are employed. For example, an ice-hockey game with some power plays might provide more of a test of more varied skills than one in which two evenly matched teams continually struggle at center ice with few shots on goal by either side." (Simon 2005: 91)

Simon states that sometimes the constitutive skills do not provide enough of a test, so we need to resort to the SF to test the teams by their restorative skills. Of course, we are entering an infinite regress here - the same could be said about the testing merits of restorative skills, and so on. As a consequence, we might have to resort to other types of strategic fouling to provide for a better test. Thus we would be moving further and further away from the idea that games primarily test the constitutive skills of the competitors.

In the later stages of tournaments (e.g. the World Cup), where a game ends in a tie, there are usually procedures in place (via the rules of the game) which will help to crown a winner. Here, the testing of constitutive skills did not determine any team to be better. In football, if after extra time the score remains tied, the test moves to restorative skills (the penalty shoot-out). However, note that it is not up to players to alter what is being tested - the rules determine this. Simon's so-called 'judicious' SF usurps the authority of the gamewright (or the sport's governing body) and alters the nature of the contest.

Simon presents us with the following scenario:

"Teams A and B are meeting for the third time this basketball season. Team A won the first game by 3 points and Team B the second game by 4 . So far in the deciding contest of the season, the teams remain equally matched. Let us suppose that play so far in all three games

12

Suits introduces a third type of rule (-violation): "But these rules and the lusory consequences of their violations are established by the constitutive rules and are simply extensions of them." (Suits 2005: 51) I have dedicated a separate paper to Suits' account of the SF (Imbrišević 2019).

13

However, I have been told that some youngsters have adopted strategic fouling into their game.
Circa from the 19th-century onwards, when the rules of many of our popular games were codified.

15

I am introducing the figure of the 'wily coach' to stand for coaches who look for new ways to use the rules of a game in order to gain an unearned advantage over their opponents.

16

Peter Czerne reminded me that "law is also not self-reflective in this sense, or at least not sufficiently". 
clearly indicates that in terms of constitutive skills the teams are roughly equal in ability. In the present game, which determines a slot in the postseason playoff, the score is tied until the last few seconds when Team A scores a go-ahead field goal. B misses its chance to tie the game. Team A has a lead of 2 points and possession of the ball with 9 seconds left in the game." (Simon 2005: 92)

Simon claims that strategic fouling in the last 9 seconds of the game is a better test since the constitutive skills of both teams are roughly equal. First, if teams are roughly equal, this makes for a good contest; we do not want to see unequally matched teams. Second, provided that the team in the lead can hold on to the ball for the last 9 seconds, the score tells us that this team has got the edge over their opponents. Their constitutive skills may be roughly equal, but their performance is (at this point) superior. Simon advocates that we should permit the trailing team to foul to catch up on the score because this would be a better test of skill - and it would give them the chance to win. However, as long as one team is ahead, with 9 seconds to go, the test has (virtually) been decided. It does not matter that it has been decided by a narrow margin - this indeterminacy right until the end makes for exciting games.

Fraleigh (2003: 271) recognises that the display of skill is central to a game. However, his rejection of the SF rests on weighing the importance of constitutive skills against restorative skills. Fraleigh fails to state clearly that they are normatively not on a par; more precisely, restorative skills are not normatively neutral - they only come into being through a rule-violation. For this reason, restorative skills are not desirable in a game - their use is to be minimised rather than promoted. Highlighting this point would allow Fraleigh to deflate Simon's riposte:

“... not all exercises of restorative skills are routine or require less skill than constitutive skills require.” (Simon 2015: 69)

Simon claims that strategic fouling "raises the competitive intensity of the game and creates more of a test for the players than simply letting the leading team run out the clock" (Simon 2005: 95). There is nothing wrong with running out the clock when you are in the lead. Spectators might not like it and might prefer an attacking game, but this strategy is permitted by the rules of our most popular games. Things are different in martial arts; there you are supposed to engage your opponent, and the referee exhorts the competitors to do so. It is against the rules to avoid the fight (e.g. by stepping out of the fighting area in Tae-Kwon-Do). However, when you run down the clock in basketball (or football), you are still engaging your opponent. There is a standing challenge by the team in possession to engage in constitutive play: Come and get the ball, if you can!

Furthermore, it does not matter that some of the trailing team's players are poor at converting free-throws. Simon awards to the trailing team (or their coach) a power to break the rules to change the nature of the test. However, it is not up to the coach or the players of one team to change the nature of the contest unilaterally. After all, both teams agreed (implicitly) to abide by the rules of the game. If you wish to change a bi-lateral agreement, you need to consult the other side first (or the rule book).

The fact that most professional sides have adopted strategic fouling does not mean that players have the authority - imputed to them by Simon - to alter the nature of the test and break the rules. It also does not mean that we have a level playing field; it only means that, in a close game, the side who is last in employing a SF, before time runs out, wins the game. Then, 'skilful' fouling may overturn a lead which was gained through constitutive skills. 
It might be useful here to consider whose interests are affected when a SF allegedly makes for a 'more complex and interesting' game. Professional players make a living from their sport and employing the SF might give them the competitive edge to keep winning or to do better overall. If the practice is wide-spread, there is great pressure to accept the SF in your game plan; if you do not, you might be at a disadvantage. Thus, the players are often extrinsically motivated, ${ }^{17}$ rather than by what the game and its rules demand. ${ }^{18}$ I doubt that players see the game as more complex and interesting when a SF is being used. On the contrary, in basketball, constant free throws are most likely boring the spectators (Torres 2018: 12; Russell 2017: 31).

Also, the player who is being fouled will be frustrated by such an act. When we are dealing with 'cynical' $\mathrm{SFs}^{19}$ the disapproval is even greater. Spectators and players alike know that the SF is an infringement of the rules, that it disturbs the free flow of the game and that it inhibits the players' ability to display their skill.

Let us grant Simon's claim that SF makes games more interesting. Sometimes it may be the case that the exercise of so-called 'restorative' skills is - temporarily - thrilling for the audience: the penalty kick in football, for example, or the Penalty-Kill-Mode in ice hockey. ${ }^{20}$ However, we must not forget the downside. Play is interrupted, and this can be a source of frustration for the viewers and the fouled team. If thrill were all that counts, then we could ask for more fouls in order to increase the thrill. However, this would alter the nature of the game because it would shift the focus from the ideal of free-flowing play to frequently interrupted play. Furthermore, it (unnecessarily) increases the risk of injury to players, ${ }^{21}$ and if an injury ensues, it would diminish the equality of competition (cf. Loland 2002: 98). The beauty and skill of uninterrupted play would get lost. I submit that this is the essence of playing a game and this explains why we enjoy it so much - be that as players or as spectators.

For Simon (2005: 93), strategic fouling makes for a more exciting game. However, why should the audience's desire for excitement determine the players' attitude towards the rules of the game? Keep in mind that the team in the lead presumably earned their lead through constitutive skills. The practice of stopping-the-clock might deprive them of this lead, and if they were plan-

17

I am not excluding the possibility that a professional player's main focus is on playing rather than winning. The instrumental benefits of being a professional are then just sideeffects for this player.

18

Suits (1988: 8): “... when games become instruments for external purposes (most obviously for acquiring money, as in the form of salaries drawn by players in the NHL, CFL, and so on), then these games, just like their players, lose their amateur standing. (...) such games are not played primarily out of love of the game but out of love of what the game can produce, whether playing it is loved or not." Cf. Morgan (1987: 16).

19

Examples are Maradona's and Thiery Henry's use of hand-ball or bringing down a striker from behind who is in a good position to score. See: Ogden (2019).

20

The offending team is down by one player and has to kill the, now improved, opportunities of the opposition to score, until the penalised player is allowed to return. 21

Dean Smith surmises that college basketball has become rougher with the introduction of TV coverage. Sports commentators and TV producers do not like a strict application of the rules: "No official wants to be criticized on television. He can be sure that he won't be criticized if he doesn't call fouls away from the ball - and this is where most of the rough, illegal play exists: away from the ball." (Smith 2003: 137) 
ning to have another go at scoring, the SF deprived them of exercising their constitutive skills.

I submit that a game represents a fair measure of skill and performance of the competitors. Simon focuses on measuring constitutive (and restorative) skills in his justification of the SF, but he ignores the performance issue. The teams may be roughly equal in constitutive skills, but as long as one team is ahead in the score, they have performed better. Why shouldn't we let that team win? Even if the score were tied at the end of a game, this would not warrant strategic fouling. Such a score reflects equality in skill and performance. Here is where the little word fair becomes important. If we allowed strategic fouling, it would destroy the idea that a game represents a 'fair' measure of skill and performance.

It may be true that many professional athletes give a 'performance', similar to actors on stage, who are there to entertain (and educate) the audience. However, even actors should follow the playwright's script, rather than making up their lines themselves. Similarly, athletes should follow the "script of the gamewright'. They should accept and be guided by the rules of the game (i.e. adopt the lusory attitude) rather than by what they imagine to be the desires of the audience. Doing the latter would have a corrupting influence on the game - think of Plato's simile of the beast in The Republic.

However, I would contest Simon's claim that sports fans find games where deliberate fouls occur more interesting and exciting. Concerning constant free-throws at the end of basketball games, NBA commissioner Adam Silver stated:

"Not only is that something that is bad for our network partners, but for [sic] all of the fan research we have shows that the fans hate it." (Zillgitt 2016)

Joseph Raz (1999: 116) has pointed out that games rely, among other mandatory norms, on the 'continuity norm', i.e. we cannot wait forever for the other chess player to make a move. We need to 'keep the game going', and this means, for ball games, to keep the ball in play. ${ }^{22}$ Thus, the Razian continuity norm equally urges against intentional interruptions to the flow of the game through fouling. ${ }^{23}$

If we were to accept and encourage the SF, then fouling would become a new 'skill' - we would have to add it to the existing skill-set for players. Imagine the SF of 'taking out' the star striker of the opposing team - with as little risk of injury to the violator, but with maximum or sufficient force to achieve the aim. This may not be the defender's decision but a team order by the coach. If the foul were done clumsily (causing injury to the defender as well as to the striker, or incurring a harsher penalty than envisioned), the purpose of strategic fouling (i.e. to gain an advantage) would not be achieved.

Let us say that as a result of the SF the star striker is taken off the field on a stretcher and is unavailable for the rest of the game. The fouling defender is given a red card, and thus her team is also one player short. Provided there are any substitutes left, the injured player can be replaced and this team is now one player up. However, the fouling team retain - or better, have created - an unfair advantage through violating a rule: the scoring ability of the star striker has been removed. ${ }^{24}$

For both teams such a strategy subverts a central aim of games - unless their supreme value is winning at all cost. Riordan explains that the interests of opposing teams converge in one important respect: 
“... although their interests as competitors are mutually opposed, they share a common interest in maintaining fair conditions of competition." (Riordan 1996: 19)

It may very well be that the miscreant side, who excel at fouling but not at play, will win the contest; or they lose, but not as badly as their playing skills would suggest. As a result, the score will most likely not reflect the constitutive skills of the competing players. Thus one important purpose of the game has been subverted: a fair determination of the better side.

\section{Simon writes:}

“... basketball games that involve the judicious use of strategic fouls might be more complex and interesting and provide a more stringent test for the participants than one in which such a practice is disallowed or absent." (Simon 2005: 91) ${ }^{25}$

One might get the idea that the 'judicious' SF is an exception to the rules; just like in the football rule which forbids handling the ball - except for the goalkeeper. But the rules are silent about the 'judicious' SF, so it cannot be that.

The adjective 'judicious' suggests that a coach or player if in possession of enough nous, may break the rules - effectively overruling the rules. As a consequence of adopting such a view, many referees might then be more lenient when penalising a SF. Moreover, many off-the-ball fouls in basketball are not called, and naturally, the game becomes rougher. However, it also makes

"... the officials too important. They begin to pick and choose what to call, which is not fair to them, and certainly not fair to the players." (Smith 2003: 138)

Also, the teams become aware of this:

"In the same way that teams will scout an opponent for offensive and defensive tendencies, they also scout officiating crews. Teams try to decipher what kinds of penalties they call and how often, and then prepare their players for the tendencies. Some coaches go as far as using a PowerPoint presentation to inform their players and assistant coaches about what to expect on Sunday." (Kirwan 2012)

Simon's approach introduces an epistemological problem: whose judgement is 'judicious'? He overlooks an important feature of human psychology. Few athletes will feel that their judgement is not 'judicious'. This insight about human psychology was acknowledged a long time ago by Descartes in the opening paragraph to his Discourse on the Method (1637). The introduction of the 'judicious' SF merely complicates matters (which SFs are judicious

22

The advantage rule in Association football as well as in Gaelic football confirms the Razian view.

23

Suits in his discussion of open games (Chapter 12 of The Grasshopper) accepts that they rely on (2005: 120) 'the principle of prolongation', i.e. keeping the action going, so that the game continues as long as is desirable. But this principle of course differs from, what I would term, the implied rule of closed games: Avoid interrupting the flow of the game! See also: Butcher \& Schneider (1998: 17).

24

Wright and Hirotsu (2015: 167) report that after the imposition of a red card for a SF "no statistically significant change in goal-scor- ing rate was found for a team playing with 10 men when analysing the 1999-2000 EPL season (this was also found by Ridder et al for the Netherlands League)". This might mean that in football the penalty of exclusion 'undercompensates' the victim side. Thus the restorative function of penalties fails and this undermines the game itself, because the idea of a fair measure of performance is subverted.

25

Also in: Simon et al. (2015: 70). Russell (2017: 33), although criticising Simon's approach to the SF and the vagueness involved, nevertheless approves of the 'judicious use' of strategic fouling, because it makes for better sport. 
and which are not?) and diminishes the authority/guidance provided by the rules (and the referee).

Furthermore, Simon's approach to games would measure and test different skills:

"... the tactical skill of assessing consequences of rule infractions." (Butcher \& Schneider 1998: 17)

It would turn it into a different game, as Butcher \& Schneider have pointed out, using football as their example:

"Soccer is a game where, relatively speaking, the play is continuous. Allowing players to constantly consider the relative cost of breaking the rule is likely to result in more rule-infractions and hence more stoppages. This would change the nature of the game for the worse. (...) If handling the ball is a constant option (especially outside of the penalty area), traditional soccer skills will become of less value." (Butcher \& Schneider 1998: 17-18)

Furthermore, wouldn't many more situations be 'judiciously' assessed to require a SF? Many more rules could be broken if we adopted this view. ${ }^{26}$ Russell writes:

"If strategic fouling is permitted to decide something as important as the outcome of a game through the use of restorative skills, it is unclear why it cannot be justified earlier in a game to give a losing team a better chance to use its constitutive skills to win." (Russell 2017: 4)

This is indeed a trend we can observe in football.

Let us now turn to the claim that the rules might encourage strategic fouling. Simon writes about basketball:

"... some features of the rules create an incentive for teams to strategically foul at the end of close games in order to trade 2 points for a chance of making 3, thereby calling into question whether in such contexts foul shots really are intended to be punishments for forbidden behavior or the price of strategic choices." (Simon 2005: 94f.)

The obvious reply to this is that the gamewright did not intend the 3-2 advantage for the fouling team (resulting from the practice of stopping-the-clock). It is a weak spot in the rules (cf. Berman 2011: 1347), which was 'discovered' as a strategy by a wily coach. John Naismith, the inventor of basketball, did not envisage that his original 13 rules would 80 years later give rise to this particular SF. His motivation for basketball was to invent an indoor game over the winter period, which would reduce the risk of injury. For this reason, the game was to discourage tackling or any other form of physical contact between players. Naismith reports about the inaugural game in 1891:

"The players seemed to heartily enjoy the rough and tumble of the game, especially the effort to keep from personal contact with the opponents." (quoted in Rains 2009: 45)

The recent practice of stopping-the-clock relies on personal contact by fouling a player off the ball. However, rule 5 of Naismith's original 13 rules reads:

"No shouldering, holding, pushing, tripping, or striking in any way the person of an opponent shall be allowed; the first infringement of this rule by any person shall count as a foul; the second shall disqualify him until the next goal is made, or, if there was evident intent to injure the person, for the whole of the game, no substitute allowed." (Rains 2009: 43)

Of course, a game develops over time. Basketball is much more physical nowadays than at its inception. Free-throws for a foul were added in 1894. However, they were not added as an encouragement to commit SFs. The wily coach is always looking for ways to exploit the rules to gain an advantage and Don Nelson, the Dallas Mavericks coach, found that the practice of stopping- 
the-clock did just that. He is credited with refining the practice by targeting the weakest free-thrower of the opposing team.

Terry Holland, a former basketball coach, stated in 2010:

"The current situation that allows the defensive team to foul (intentionally) and limit the offensive team to a maximum of 2 points on that possession is not fair now that the team gaining possession after the free throws has the option of trying for 3 points on their possession. An intentional foul should not give the team fouling a 3-2 advantage for the respective possession." (Glier 2010)

The unearned advantage resulting from strategic fouling is also present in other sports. Take football: bringing down a striker 'skilfully' just outside the penalty box who is in a good position to score, because they are only facing one defender, might result in a red card. But the offender's team have averted the likelihood of conceding a goal. I do not see why Simon's justifications for strategic fouling could not apply in the given example. If winning is the supreme value, as it seems to be for practitioners and apologists of the SF, then utilising the SF in many other situations and sports is the right (and judicious) thing to do. ${ }^{27}$

It is not just deliberate rule-breaking which is on the rise; we have also seen an increase of cases of doping and other forms of cheating (e.g. diving in football). The historian Christopher Lasch does not think it is (1979: 117) "the cult of victory, or the obsession with achievement" which might explain the crisis in athletics but the "collapse of conventions that formerly restrained rivalry even as they glorified it". However, we need to ask: why did these conventions collapse? I would suggest that "the will to win" swept them away. UCLA Bruins football coach Henry Russell Sanders is credited with the adage (during a Cal Poly San Luis Obispo physical education workshop in 1950):

"Men, I'll be honest. Winning isn't everything." [and after a long pause] "Men, it's the only thing!" (quoted in: Rosenbaum 1950)

And another famous saying by Sanders is:

"Beating SC is not a matter of life or death, it's more important than that." (quoted in: Walk 2004)

By contrast, consider what the Australian tennis player John Newcombe said after his Wimbledon defeat in 1974:

"It's not as though it's the end of the world. I mean, it's not as though you were divorcing your wife and having a friend die, or something like that. That really would be unbearable; this is not." (quoted in: Aspin 1975: 60)

26

"For if this attitude is taken (...) it could, presumably, be taken for any rule." (Butcher \& Schneider 1998: 17)

27

Carolyn Cusick and Mark Peter (2014) present an interesting analysis of the issue. They claim that the SF at the end of a game is a form of fallacious reasoning, which they term 'the last straw fallacy'. This fallacy "occurs when a person claims that certain moments or people at the end of a series are causally decisive and as such more important. When this way of reasoning about the entire game becomes commonplace, the nature of the practice begins to change fundamentally. (...) this improper focus on one part in the causal series may contribute to a form of strategic thinking that alters common values of fair play. We can see how, particularly in sports with time clocks, the emphasis on the last chance often leads to unethical tactical plays such as the intentional foul". There is a related issue: the temporal variance of enforcing game rules, particularly towards the end of a game. For a discussion see (Berman 2011). 
It is noticeable that the emphasis on winning, as the supreme value, is rarely admitted among supporters of the SF (cf. Flynn 2017). The primary reasons given are that it makes for a better test or a more interesting and exciting game. Take Simon's "two evenly matched teams [who] continually struggle at centre ice with few shots on goal by either side" (2005: 91). There is nothing wrong with evenly matched teams; we do not want there to be a big gap in skill, because this would make for a one-sided game. ${ }^{28}$ Such a game would turn into a 'lesson' (Kolnai 1965-1966: 115). Also, some games end in a tie, which means that the teams are equals in skill. Simon, presumably for cultural reasons ('the winning mentality'), feels the urge to break the deadlock on the ice - and this can only be done through a foul.

Simon writes that SFs can be ethically appropriate when certain conditions are met. One of them is:

“... the team that strategically fouls has no alternative strategy based on the use of constitutive skills that gives it a reasonable chance to win." (Simon 2005: 93)

Breaking the rules at the end of a close game might be the only way to win. Even young players are encouraged to adopt this strategy. Miller and Coffey, in a book aimed at young female basketball players, write:

"Know the difference between a smart foul and a dumb one. A smart foul is when the score is close and an opponent is going up for a lay-up and you're the only one who can stop her. If you foul her, so what? She gets two free throws, but chances are she would've had a sure two points anyway if you'd just let her go." (Miller \& Coffey 2009: 133)

Several questions come to mind: does a potential victory have any (enough?) normative force to justify breaking the rules? How much merit does a victory based on rule-violation have? How much enjoyment can be derived from such a victory? What effect does this have on our attitude towards game rules? Does the greater willingness to transgress (game) rules carry over into everyday life? I leave it to the reader to ponder these questions. ${ }^{29}$

\section{Game Conventions}

Simon (2005: 88), just like D'Agostino, Moore and Vossen, believes that some SFs have become part of how a game is played, i.e. part of its 'social conventions and practices'. Simon's apologia for the SF is an attempt to build a wide-spread practice into the rules retrospectively. He is trying to ascribe normative force to this practice because it has become more common. Note that this is, in fact, how linguistic rules acquire their normative force. Devries explains:

"Well-entrenched patterns of behavior in a community are retrospectively endowed with a normative status they did not originally have, because the community comes to endorse that pattern of behavior as community members come to acquire the explicit conceptions of an 'ought' and a rule." (Devries 2013: 263) ${ }^{30}$

Although some SFs become well-entrenched in professional leagues, their normative status has not changed - they remain fouls.

\section{Cesar Torres writes:}

“... the acceptability of a practice depends on the soundness of the supporting arguments rather than only on how extensive the practice has become in the sport community. Otherwise, the members of a sport community risk capitulating to the ethos and surrendering their critical capacity to understand, value, and appreciate sport. An ethos is clearly not beyond moral scrutiny. My analysis of skills was precisely meant to provide a framework to determine not only what 
should count as part of sport but also what should count as central and peripheral. Part of my effort was to answer the relativist outlook implicit in recurrent pleas that a practice is acceptable because 'it is part of the game'." (Torres 2018: 7f.)

The governing bodies are not endorsing the SF - they are trying to curb it. Furthermore, as Fraleigh (1982: 42) has pointed out, it is not certain that all involved agree to include the 'good' foul in their repertoire of moves (cf. Eylon \& Horowitz 2018: 9).

In Simon's account of the SF, there is tension between a wide-spread practice and its lack of normative force. Perhaps this explains why Simon struggles to provide a criterion for distinguishing the 'good' from the 'bad' SF. ${ }^{31}$ Simon writes:

"The use of strategic fouling to deprive an opponent of an advantage already earned through the exercise of constitutive skills also is morally questionable." (Simon 2005: 94)

Simon seems to be contradicting himself here. ${ }^{32}$ Tripping up a player from behind who has outplayed me is depriving him of an earned advantage. However, why is fouling a player, off the ball, acceptable to stop the clock, because you are now depriving the whole team of the advantage of being ahead in the score? The team achieved this advantage through outplaying the opposition - using constitutive skills. ${ }^{33}$ Furthermore, rather than running out the clock, they might want to mount another attacking run, and the SF deprives them of this possibility. The 'judicious' strategic fouler cannot exclude this possibility - she is merely guessing.

To break the rules openly and deliberately to gain an advantage is a form of villainy. The SFer treats her (direct) victim as an object, as a means to an end, rather than as a com-petitor. Dellatre writes:

"When a person violates the rules which govern competition, he treats his opponents as means merely to his end of victory." (Dellatre 1975: 136)

Why is this worse than cheating? The cheater breaks the rules in secret, hoping not to get caught, but pretends to follow them. They neither undermine the purpose of the rules nor does an attempt at cheating erode the game. The cheater makes an exception for themselves but insists at the same time that others abide by the rules. Thus the cheater accepts that the rules ought to be followed. If cheating remains undetected it does not degrade the game as such (but it means that certain instances in particular matches were not

28

Vossen agrees (2008: 185): “... the intrinsic rewards of a competitive game are most readily attained within genuine contests characterized by evenly matched and challenging opponents." Similarly: Dellatre (1975: 134).

29

For criticism see also: Russell (2017: 28f.).

30

I will give a recent example from the English language. The historical meaning of the verb 'decimate' (to reduce by a tenth) has lost ground and, unfortunately, it is now widely accepted, and seen as correct, that it can also mean: to kill, to destroy. Consequently, the historical meaning will eventually get lost, which results in an impoverished language.
This weakness is also recognised by Russell (2017: 3)

32

“... under normal circumstances, the winning team's advantage both in having possession of the ball and being ahead by two points has been earned through due execution of game skills, in particular, successful execution of constitutive skills plus successful execution of restorative skills where contestants were illegally prevented from exercising constitutive skills and were entitled to compensation." (Russell 2017: 4)

33

There may also have been an element of luck. 
as they seemed); if the cheater is caught, it serves as a re-affirmation of the importance of the rules. The SFer, on the other hand, openly undermines the purpose of the rules: to protect each competitor's right to display their skills. At the same time, the practice is eroding the purpose of the game: a fair measure of competitive performance. The SFer does not accept that rules ought to be followed; they are defeasible whenever a SF seems appropriate.

The strategic fouler gives herself more options than are provided by the rules of the game: the option to break the rules. This is well understood by Kathleen Pearson (1995). ${ }^{34}$ However, many practitioners and some philosophers view game rules as conditional proposals. Moore writes:

"Thus, the constitutive rule gives players a choice: they may either follow the rule or break it and be penalized." (Moore 2017: 101)

I have argued that this view of rules is conceptually mistaken (Imbrišević 2018). Gamewrights do not offer rule-breaking as a way of playing the game - only practitioners, (usually professional players who are under immense commercial pressure), may see it that way. Similarly, the criminal law, as a system of rules, does not offer its violation as an option - although some criminals might take this view.

\section{Conclusion}

Why should a - now - wide-spread practice alter, i.e. weaken, the normative force of particular game rules? Presumably, a particular practice (of strategic fouling) only became wide-spread because other competitors did not want to be disadvantaged, rather than everyone whole-heartedly agreeing that employing this particular SF was a great idea.

It is also difficult to see why some SFs are acceptable, and others are not. Simon provides the most worked out account, but ultimately it is up to the practitioner to decide whether to resort to a SF in a particular context. Simon's notion of the 'judicious use' of strategic fouling is too vague, and as a consequence, a player usurps the authority which normally inheres in the rules of the game. Practitioners are less discriminating than Simon; they use the SF whenever it is convenient and consider this to be a 'judicious use' of the SF. Thus, over time, the pool of acceptable SFs will increase, and it is likely that the apologists of the SF will again feel called upon to provide a justification post factum - once the practice is wide-spread.

The end of a game is tied to the observance of its rules. ${ }^{35}$ Playing the game (and, while doing so, attempting to score points to win) is only worthwhile if I have played by the rules, i.e. I have outplayed the opposition, rather than using more efficient means (e.g. handling the ball in football) strategically to gain an unearned advantage.

The word 'competition' (Latin: com petere) means to make for, to strive, to seek - with another. This suggests that "you seek to bring out the best in each other through presenting a worthy challenge. You strive for and achieve excellence together" (Boxill 2014: 343). It is doubtful, however, whether the SFer is still competing in this sense.

Young players will, of course, emulate their idols. This means, for example, that the SF might eventually mar football on the village green, in the school yard and in amateur leagues. At the same time, it would eventually change our perception of what the principle of Fair Play demands. 
There are at least three main objectives or desires in playing a game: 1 . the pleasure of playing with others; 2 . the pleasure of displaying (primarily) your constitutive skills; 3 . the pleasure of winning. In a SF, the pleasure of winning is given the greatest importance. If winning (at all cost) is the supreme value, then the enjoyment of playing and displaying your skills is made to be subordinate to winning. ${ }^{36}$ I would contend that we primarily engage in games because we enjoy playing. Winning (or losing) are possible consequences of playing, side-effects, so to speak; they are not the reason why we play games - think of your childhood. Kolnai writes:

“... the player's primary aim is to play chess rather than to win.” (Kolnai 1965-1966: 104)

However, note that for the professional, the primary aim might be to win. Gadamer explains:

"Thus we can say that, for the one who is playing, play is not for real; and it is just for this reason that we play." (Gadamer 1990: 108) ${ }^{37}$

Referring to Aristotle, Gadamer explains that play is a form of respite - from the usual business of life. It is a contrast to that world which is driven by the seriousness of its ends. I submit that favouring winning over other pleasures of playing threatens the experience of respite and introduces the (external) seriousness of ends into play. We are 'serious' when we play, but this differs from the seriousness in the business of life:

"Play can only fulfil its purpose when the player is lost in play. It is the seriousness of being in play, and not the reference to a seriousness of purpose, outside of the game, which allows play to be wholly play." (Gadamer 1990: 107f.) $)^{38}$

I suspect that the 'professional' who regularly employs the SF views play as the serious business of life; thus, the realm of play and the realm of the business of life become indistinguishable for the professional.

We enjoy winning, of course, but within the boundaries of the rules and our sense of fair play. Joseph Raz rightly points out:

"Playing beautifully and in a sportsmanlike way are values often regarded as even more important than winning." (Raz 1999: 120f.)

Furthermore, knowing that your victory is not based on fair competition or was won by dubious means diminishes the value of this victory.

What is the purpose of the rules of the game? Is it merely to facilitate that one side may be victorious? ${ }^{39}$ Friedrich Georg Jünger (1953: 99) argues that a

34

Hart (1997: 27) agrees that a criminal statute is not a conditional proposal; see also Rawls (1999: 276f.), Fischer (2012: 114) and Migotti (2017: 389). For a wider discussion see Chapter 5 of (Imbrišević 2014).

35

See: Suits (2005: 42)

36

See: Tasioulas (2006). For a contrary view see: Flynn (2017).

37

"So läßt sich etwa sagen, daß für den Spielenden das Spiel nicht Ernstfall ist, und gerade deswegen gespielt wird."
"Nur dann erfüllt ja Spielen den Zweck, den es hat, wenn der [108] Spielende im Spielen aufgeht. Nicht der aus dem Spiel herausweisende Bezug auf den Ernst, sondern nur der Ernst beim Spiel läßt das Spiel ganz Spiel sein." Friedrich August Weißhuhn expresses similar sentiments in his essay "The Game in its Strictest Meaning" ("Das Spiel in strengster Bedeutung") from 1795.

Or to allow for a draw. 
central function of the rules of a game is to facilitate the display of skill. The rules are supposed to protect this display of skill, rather than offering its violation as an option. Apologists of the SF are ignoring this principle.

Before the beginning of a contest, one can often hear the invocation: May the best team/player win! The SF, like any other foul, curbs the display of skill of fellow competitors and thus distorts the final score. As a result, the best team may not win.

Contrary to Simon, strategic fouling is not a better test but a sign of desperation - the trailing team has run out of licit options. Simon's apologia for strategic fouling is merely an attempt to give a common practice the sheen of respectability. However, what is underneath the practice, is rotten - just as the etymology of the word 'foul' suggests.

\section{Bibliography:}

Aspin, D. (1975): "Ethical Aspects of Sport and Games and Physical Education", Journal of Philosophy of Education 9 (1975) 1, pp. 49-71. doi: https://doi.org/10.1111/j.14679752.1975.tb00434.x.

Berman, M. N. (2011): “Let 'em Play': A Study in the Jurisprudence of Sport”, The Georgetown Law Journal 99 (2011), pp. 1325-1369.

Butcher, R.; Schneider, A. (1998): "Fair Play as Respect for the Game", Journal of the Philosophy of Sport 25 (1998) 1, pp. 1-22. doi: https://doi.org/10.1080/00948705.1998. 9714565.

Couse, S. (2019): "Handball rules among those changed by Ifab for next season", $B B C$ Sport (2 March 2019). Available: https://www.bbc.co.uk/sport/football/47429316 (Accessed on 4 December 2019).

Cusick, C.; Peter, M. (2014): "The Last Straw Fallacy: Another Causal Fallacy and Its Harmful Effects", Argumentation 29 (2014) 4, pp. 457-474. doi: https://doi.org/10.1007/ s10503-014-9339-x.

D'Agostino, F. (1981): “The Ethos of Games”, Journal of the Philosophy of Sport 8 (1981) 1, pp. 7-18. doi: https://doi.org/10.1080/00948705.1981.9714372.

Dellatre, E. J. (1975): "Some Reflections on Success and Failure in Competitive Athletics", Journal of the Philosophy of Sport 2 (1975) 1, pp. 133-139. doi: https://doi.org/10.1 080/00948705.1975.10654105.

Devries, W. A. (2013): "All in the Family", in: Ryder, D.; Kingsbury, J.; Williford, K. (eds.), Millikan and Her Critics, John Wiley \& Sons, Chichester, pp. 259-275.

Dixon, N. (1999): "On Winning and Athletic Superiority", Journal of the Philosophy of Sport 26 (1999) 1, pp. 10-26. doi: https://doi.org/10.1080/00948705.1999.9714576.

Eylon, Y.; Horowitz, A. (2017): “Games, Rules, and Practices", Sport, Ethics and Philosophy 12 (2017) 3, pp. 1-14. doi: https://doi.org/10.1080/17511321.2017.1334696.

Fischer, D.-P. (2012): "Moral im Profifußball. Eine philosophisch-ethische Analyse", in: Brandt, Ch.; Hertel, F.; Stassek, Ch. (eds.): Gesellschaftsspiel Fußball Eine sozialwissenschaftliche Annäherung, VS Verlag für Sozialwissenschaften, Wiesbaden, pp. 107-123.

Flynn, E. (2017): "Strategic fouls: a new defense", Journal of the Philosophy of Sport 44 (2018) 3, pp. 342-358. doi: https://doi.org/10.1080/00948705.2017.1361330.

Fraleigh, W. P. (2003): "Intentional Rules Violations - One More Time", Journal of the Philosophy of Sport 30 (2003) 2, pp. 166-176. doi: https://doi.org/10.1080/00948705.20 03.9714642 .

Fraleigh, W. P. (1982): "Why the Good Foul is not Good", Journal of Physical Education, Recreation \& Dance 53 (1982) 1, pp. 41-42. doi: https://doi.org/10.1080/07303084.1982. 10629279. 
Fricker, E. (2017): "Norms, Constitutive and Social, and Assertion", American Philosophical Quarterly 54 (2017) 4, pp. 397-418.

Gadamer, H.-G. (1990): Wahrheit und Methode, J. C. B. Mohr, Tübingen.

Glier, R. (2010): "Does the Ending Need Rewriting?", The New York Times (23 March 2010). Available at: http://www.nytimes.com/2010/03/24/sports/ncaabasketball/24fouls. html (accessed on 4 December 2018).

Imbrišević, M. (2020): "Compensation, Restitution and the Strategic Foul” (forthcoming).

Imbrišević, M. (2019): "Suits on Strategic Fouling", Sport, Ethics and Philosophy (published online, 20 March 2019). doi: https://doi.org/10.1080/17511321.2019.1584827.

Imbrišević, M. (2018): “The Strategic Foul and Contract Law: Efficient Breach in Sports?”, Fair Play 12 (2018), pp. 68-99.

Imbrišević, M. (2014): Carlos Nino's Consensual Theory of Punishment (PhD thesis), University of London. Available at: http://publications.heythrop.ac.uk/2369/1/Imbrisevic\%2C $\% 20 \mathrm{M} \% 2 \mathrm{C} \% 20$ Final\%20Thesis.pdf (accessed on 4 December 2018).

Jünger, F. G. (1953): Die Spiele: Ein Schlüssel zu ihrer Bedeutung, Frankfurt a. Main: Vittorio Klostermann.

Kirwan, P. (2012): "Pass interference, holding penalties on the rise in the NFL", NFL News. Available at: http://www.nfl.com/news/story/09000d5d8242fc95/article/pass-interference-holding-penalties-on-the-rise-in-the-nfl (accessed on 4 December 2018).

Kolnai, A. (1965-1966): "Games and Aims", Proceedings of the Aristotelian Society 66 (1965-1966), pp. 103-128.

Kosiewicz, J. (2011): "Foul Play in Sport as a Phenomenon Inconsistent with the Rules, yet Acceptable and Desirable", Physical Culture and Sport. Studies and Research 52 (2011) 1, pp. 33-43. doi: https://doi.org/10.2478/v10141-011-0012-x.

Lasch, C. (1979): The Culture of Narcissism: American Life in an Age of Diminishing Expectations, W. W. Norton \& Co., New York.

Loland, S. (2002): Fair Play in Sport: A Moral Norm System, Routledge, London.

McIntosh, P. C. (1979): Fair Play: Ethics in Sport and Education, Heinemann, London.

Miller, F. Y.; Coffey, W. (2009): Winning Basketball for Girls, Chelsea House, New York.

Moore, E. (2017): "Formalism and strategic fouls", Journal of the Philosophy of Sport 44 (2017) 1, pp. 95-107. doi: https://doi.org/10.1080/00948705.2016.1256781.

Morgan, W. J. (2012): "Broad Internalism, Deep Conventions, Moral Entrepreneurs, and Sport", Journal of the Philosophy of Sport 39 (2012) 1, pp. 65-100. doi: https://doi.org/10 $.1080 / 00948705.2012 .675069$.

Morgan, W. J. (1987): "The Logical Incompatibility Thesis and Rules: A Reconsideration of Formalism as an Account of Games", Journal of the Philosophy of Sport 14 (1987) 1, pp. 1-20. doi: https://doi.org/10.1080/00948705.1987.9714447.

Ogden, M. (2009): “Thierry Henry admits to handball that defeated Ireland in World Cup play-off", The Telegraph (19 November 2019). Available at: https://www.telegraph.co.uk/ sport/football/teams/republic-of-ireland/6599687/Thierry-Henry-admits-to-handball-thatdefeated-Ireland-in-World-Cup-play-off.html (accessed on 4 December 2018).

Pearson, K. M. (1995): “Deception, Sportsmanship, and Ethics”, in: Morgan, W. J.; Meier, K. V. (eds.), Philosophic Inquiry in Sport, Human Kinetics, Champain, IL, pp. 183-184.

Plato (1987): The Republic, translated by Lee, D., Penguin Books, London.

Rains, R. (2009): James Naismith: The Man Who Invented Basketball, Temple University Press, Philadelphia.

Raz, J. (1999): Practical Reasons and Norms, Oxford University Press, Oxford. 
Riordan, P. (1996): A Politics of the Common Good, Institute of Public Administration, Dublin.

Rosenbaum, A. (1950): "Indians far from Bashful at Chow", Los Angeles Times (18 October 1950), p. C3.

Russell, J. S. (2017): "Strategic fouling and sport as play", Sport, Ethics and Philosophy 11 (2017) 1, pp. 26-39. doi: https://doi.org/10.1080/17511321.2016.1266507.

Russell, J. S. (2014): "Is There a Normatively Distinctive Concept of Cheating in Sport (or anywhere else)?", Journal of the Philosophy of Sport 41 (2014) 3, pp. 303-323. doi: https://doi.org/10.1080/00948705.2013.832266.

Simon, R. L. (2005): "The Ethics of Strategic Fouling: A Reply to Fraleigh", Journal of the Philosophy of Sport 32 (2005) 1, pp. 87-95. doi: https://doi.org/10.1080/00948705.2 005.9714672

Simon, R. L. (2015): Fair Play: The Ethics of Sport, Westview Press, Boulder.

Smith, D. (2003): “Winding Down, Looking Ahead", in: Boxill, J. (ed.), Sports Ethics: An Anthology, Blackwell, Malden (MA), pp.136-143.

Suits, B. (2005): The Grasshopper: Games, Life and Utopia, Broadview Press, Peterborough.

Suits, B. (1988): "Tricky Triad: Games, Play, and Sport", Journal of the Philosophy of Sport 15 (1988) 1, pp. 1-9. doi: https://doi.org/10.1080/00948705.1988.9714457.

Torres, C. R. (2018): "What counts as part of a game? Reconsidering skills", Journal of the Philosophy of Sport 45 (2019) 1, pp. 1-21. doi: https://doi.org/10.1080/00948705.20 17.1415150.

Torres, C. R. (2000): "What Counts As Part of a Game? A Look at Skills", Journal of the Philosophy of Sport 27 (2000) 1, pp. 81-92. https://doi.org/10.1080/00948705.2000.971 $\underline{4591 .}$

Vamplew, W. (2007): "Playing with the rules: Influences on the development of regulation in sport", The International Journal of the History of Sport 24 (2007) 7, pp. 843-871. doi: https://doi.org/10.1080/09523360701311745.

Virgo, G. (2015): The Principles of the Law of Restitution, Oxford University Press, Oxford.

Vossen, D. P. (2014): “A Grasshopperian Analysis of the Strategic Foul”, Journal of the Philosophy of Sport 41 (2014) 3, pp. 325-346. doi: https://doi.org/10.1080/00948705.20 13.832262 .

Vossen, D. P. (2008): "Good Grasshopping and the Avoidance of Game-Spoiling”, Journal of the Philosophy of Sport 35 (2008) 2, pp. 175-192. doi: https://doi.org/10.1080/009 48705.2008.9714737.

Walk, A. (2004): "Rah-rah boo-hiss", UCLA Magazine. Available at: http://magazine.ucla. edu/year2004/summer04_09_03.html (accessed on 4 December 2018).

Weißhuhn, F. A. (1795): "Das Spiel in strengster Bedeutung", Die Horen, part 5, section IV. Available at: http://www.friedrich-schiller-archiv.de/die-horen/die-horen-1795stueck-5/iv-spiel-in-strengster-bedeutung/ (accessed on 4 December 2018).

Wright, M.; Hirotsu, N. (2015): "The Professional Foul in Football: Tactics and Deterrents", in: Wright, M. (ed.), Operational Research Applied to Sports, Palgrave Macmillan, Basingstoke, pp. 165-180.

Zillgitt, J. (2016): "NBA approves changes to cut down on Hack-a-Shaq situations", USA Today Sports (13 July 2016). Available at: https://www.usatoday.com/story/sports/ nba/2016/07/12/nba-approves-rule-changes-hack-a-shaq-situations/87013528/ (accessed on 4 December 2018) 


\section{Miroslav Imbrišević}

\section{Robert Simon i moralnost strateškog prekršaja}

\section{Sažetak}

Kako su sportovi postali profesionalniji, tako je pobjeđivanje postalo važnije. Naglasak na rezultatu, a ne na sportskoj vrlini i pobjeđivanju u stilu, vjerojatno objašnjava porast slučajeva strateških prekršaja. Iznenađujuće, među filozofima sporta postoje apologeti strateškog prekršaja. Rasprava o strateškom prekršaju u literaturi proizvela je tankoćutna razlikovanja (npr. Cesar Torres: konstitutivne protiv restorativnih vještina) i nevjerodostojna razlikovanja (npr. D’Agostino: 'nedopušteno', ali 'prihvatljivo' ponašanje). U ovom radu iznosim pregled obrane strateškog kršenja, autora Roberta Simona, te zaključujem da njegovo opravdanje nije uvjerljivo.

\section{Ključne riječi}

Robert Simon, strateški prekršaj, profesionalni sport, sportska vrlina

\section{Miroslav Imbrišević}

\section{Robert Simon und die Moralität des strategischen Foulens}

\section{Zusammenfassung}

Je professioneller der Sport geworden ist, desto wichtiger wurde das Gewinnen. Diese Betonung der Ergebnisse und nicht der sportlichen Tugend und des Siegens mit Stil erklärt wahrscheinlich die zunehmende Häufigkeit des strategischen Fouls. Überraschenderweise hat das strategische Foulspiel unter Sportphilosophen einige Apologeten gefunden. Die Diskussion über das strategische Foulspiel in der Literatur hat subtile Unterscheidungen (z. B. Cesar Torres: konstitutive Fertigkeiten gegenüber restorativen Fertigkeiten) sowie unglaubwürdige Unterscheidungen (z. B. D’Agostino: ,unzulässiges', aber, akzeptables 'Verhalten) ergeben. In diesem Artikel bespreche ich Robert Simons Verteidigung des strategischen Foulens und komme zu dem Schluss, dass seine Rechtfertigung nicht überzeugend ist.

\section{Schlüsselwörter}

Robert Simon, strategisches Foulen, Profisport, sportliche Tugend

\section{Miroslav Imbrišević}

\section{Robert Simon et la morale de la faute stratégique}

\section{Résumé}

Avec la professionnalisation du sport la victoire a pris une importance grandissante. L'accent mis sur le résultat, et non sur la vertu sportive et sur la victoire obtenue avec élégance explique probablement l'incidence croissante des fautes stratégiques. Il est étonnant que parmi des philosophes du sport il existe des apologistes de la faute stratégique. Les débats sur les fautes stratégiques dans la littérature ont aussi bien produit de subtiles distinctions (p.ex. Cesar Torres : compétences constitutives contre compétences réstoratives) que des distinctions non plausibles (p.ex. D'Agostino : comportement 'inadmissible', mais 'acceptable'). Dans cet article, je vais examiner le parti pris de Robert Simon pour la faute stratégique et montrer que sa justification $n$ 'est pas convaincante.

Mots-clés

Robert Simon, faute stratégique, sport professionnel, vertu sportive 